'I had not thought of that,' he said, somewhat abashed.

He does not seem to have considered the nature of opera. 'He couldn't write a libretto, he would write just as he always wrote.' I said 'It would attract me to try and write music for the scene in hell in Man and Superman.'

'That would be waste of work' (said S.), 'because it could bring in no profit.'

'That is not what attracts me,' I said.

'Oh, but you must reckon with that, everybody has to reckon with it. Of course, I am now a famous artist (he added, half jokingly), I can allow myself to ride hobby horses' (or something similar).

Now that was not very nice, and still less tactful.

\title{
NOTE
}

1. Presumably a reference to one of the overtures, known as Leonora I, II and III, which Beethoven wrote and rejected for his opera Fidelio.

\section{Music: VI}

\section{MARK HAMBOURG}

From Mark Hambourg, From Piano to Forte: A Thousand and One Notes (London: Cassell, 1931) p. 280. Mark Hambourg, Russian-born pianist who settled in Britain, was best known for his playing in the big Romantic tradition. He had met Shaw as a child prodigy and met him again at a postwar luncheon party, where he reports Shaw protesting at asparagus being served, as it was 'full of uric acid'.

After lunch I had some talk with Shaw, and he tried to convince me that the art of the modern pianoforte was nothing compared with that of the harpsichord. The latter was to his mind the perfect expression of keyboard music. He said he hated the modern pianoforte; it reminded him of a battle-cruiser. To which I answered that we should have been badly off during the late war without battle-cruisers. 'I don't agree,' said Shaw; 'on the contrary, if it had not been for the battle-cruisers we might have had nothing but peace.' 